\title{
PAT PINURBA
}

\author{
Oleh
}

\section{Oky Bima Reza Afrita}

Jurusan Seni Tari, Fak. Seni Pertunjukan, Institut Seni Indonesia Yogyakarta

Email: okyreza010113@gmail.com

\section{RINGKASAN}

Pat Pinurba merupakan koreografi kelompok yang terinspirasi dari konsep kiblat papat lima pancer yang berarti "empat arah yang ke lima pusat" di Jawa. Judul ini diambil dari bahasa Sanskerta, Pat berasal dari kata papat yang berarti empat, sedangkan Pinurba berasal dari kata purba yang berarti kekuasaan. Pat Pinurba dapat dimaknai sebagai empat yang dikuasai/dikendalikan.

Karya tari Pat Pinurba diekspresikan secara simbolis dan ditarikan oleh delapan penari, empat penari putra dan empat penari putri. Esensi kualitas gerak lembut dan keras (kendho dan kenceng) serta kualitas gerak dengan tempo lambat/pelan dalam teknik tari alusan Jawa yang tenang, mengalir, lambat dan detail menjadi inspirasi dasar untuk mengekspresikan karya Pat Pinurba. Karya tari ini didukung dengan video mapping, sehingga pencahayaan yang digunakan membutuhkan beberapa special light. Pendekatan koreografis yang digunakan pada karya tari Pat Pinurba yaitu sensasi ketubuhan, sensasi emosi, sensasi imaji, dan ritus ekspresi.

Kata kunci : Pat, Pinurba, Kendali, Empat

\section{ABSTRACT}

Pat Pinurba is a dance art work created as a group choreography. This title took from sanskerta language, "Pat" from the word papat which means four, then "Pinurba" from the word purba which means control. Pat Pinurba has a meaning to control the four. Kiblat papat lima pancer concept which means "four directions then the fifth is the central" in Java, was take to express Pat Pinurba.

Pat Pinurba shown symbolisly and danced by eight dancers, four male dancers and four female dancers. The soft and strong movement quality (kendho and kenceng) also the dinamic movement in alusan dance from Java which are smooth, flow, slow, and detail become a basic inspiration to express Pat Pinurba. This dance art work supported with a video mapping, so it needs a special lights. To create this choreography it used fisical sensation, emosional sensation, imaginal sensation, and ritual expression.

Key words : Pat, Pinurba, Control, Four 


\section{PENDAHULUAN}

Manusia berada dalam dunia fisik dengan panca indera, pikiran, dan intelektual (kecerdasan). Sejalan dengan panca indera, pikiran, dan intelektual yang disadari tersebut, juga memiliki panca indera halus, pikiran halus, dan kecerdasan halus, yang bila dikembangkan atau diaktifkan dapat membantu manusia untuk mengalami dunia metafisik/halus. Pengalaman dari dunia metafisik/halus inilah yang dikenal dengan pengalaman spiritual. Setiap manusia memiliki tingkat kepekaan spiritualnya masing-masing.

Pada tahun 2016, koreografer mulai tertarik dengan upacara tradisi yang dilakukan oleh masyarakat Jawa, khususnya masyarakat Jawa di Daerah Istimewa Yogyakarta. Beberapa kali koreografer mengikuti upacara tradisi, semakin sering merasakan energienergi yang tak kasat mata baik yang positif, maupun negatif. Beberapa upacara tradisi yang telah diikuti ada salah satu upacara yang menarik, yaitu upacara ritual ruwatan. Ruwatan berasal dari bahasa Jawa, "luwar saka panandhang, luwar saka wewujudan kang salah" (Poerwadarminta, 1939: 534), artinya "terbebas dari penderitaan, terbebas dari wujud yang salah". Ruwat=luwar berarti bebas, sedangkan ruwatan berarti kegiatan untuk membebaskan sesuatu yang dianggap salah/tidak wajar. Misalnya bila seseorang berbuat salah atau dalam kelahirannya tidak wajar (berlainan dari yang umum), maka orang semacam itu harus diruwat. Orang yang diruwat disebut sukerta (orang yang kotor/salah). Upacara Ruwatan sukerta diwajibkan untuk mempergelarkan wayang kulit yang biasanya dengan lakon Murwakala. Murwa $=$ murba berarti menguasai, kala berarti Bathara Kala, jadi murwakala berarti menguasai Bathara Kala. Dalam bahasa Sanskerta, bathara berasal dari kata "bhatr" yang berarti pelindung, kata "kala" berarti waktu. Jadi, secara harfiah Bathara Kala memiliki arti pelindung waktu (penguasa waktu).

Sosok Bathara Kala yang dikisahkan dalam cerita Murwakala sebagai sosok raksasa yang menakutkan dan suka mengejar manusia, tetapi dapat ditaklukkan oleh Dhalang Kandha Buwana. Fenomena dalam cerita murwakala tersebut terkadang dirasakan dalam kehidupan sehari-hari. Manusia tidak terlepas dari rasa ingin memiliki dan nafsu yang muncul dari dalam dirinya. Nafsu tersebut apabila tidak dikendalikan dengan baik akan menimbulkan sifat serakah. Ketika keserakahan tersebut menimbulkan kerugian bagi dirinya sendiri maupun orang lain, maka diri tersebut berada dalam bahaya. Untuk itu, perlu disadari adanya pengendalian nafsu manusia untuk memperoleh keseimbangan dalam kehidupan. Interpretasi sosok Bathara Kala sebagai nafsu 
ISSN: $1858-3989$

manusia dan dhalang Kandha Buwana sebagai diri manusia yang mengendalikan hawa nafsunya.

Masyarakat suku Jawa, khususnya yang berada di Daerah Istimewa Yogyakarta yang dipengaruhi Islam mempercayai bahwa keinginan-keinginan atau nafsu tersebut meliputi nafsu mutmainah, amarah, supiah, dan lauamah. Nafsu mutmainah merupakan nafsu yang mengajak manusia untuk tunduk pada kebaikan/kemurnian/kesucian. Anasir dari nafsu mutmainah ini adalah warna putih yang menyimbolkan kesucian. Nafsu amarah merupakan nafsu yang memicu manusia untuk meluapkan emosi. Warna merah adalah anasir dari nafsu amarah. Nafsu supiah adalah nafsu yang cenderung untuk mengejar kenikmatan psikis (kepuasan batin). Kenikmatan psikis bisa berupa narsis, sombong, berharap pujian, seks, dan sebagainya. Anasir nafsu supiah adalah warna kuning yang menyimbolkan kesenangan/keceriaan. Terakhir nafsu lauamah dengan anasir warna hitam adalah nafsu manusia untuk mendapatkan kepuasan biologis, seperti makan, minum, tidur, olahraga, dan sebagainya.

\section{A. Rumusan Ide Penciptaan}

Manusia memiliki empat nafsu yang sudah melekat pada raganya. Akan tetapi, bagaimana cara mengendalikan Kala dalam wujud empat nafsu manusia yang ada dalam diri manusia pada suatu proses penciptaan karya tari?

\section{PEMBAHASAN}

A. Konsep

1. Rangsang Tari

Berawal dari ketertarikan terhadap sebuah upacara ritual ruwatan yang ada di Jawa, khususnya Daerah Istimewa Yogyakarta. Pada umumnya dalam sebuah upacara ritual ruwatan di Jawa selalu menggelarkan pertunjukan wayang dengan lakon Murwakala. Murwakala merupakan cerita yang dipercaya oleh masyarakat Jawa sebagai cerita wayang yang sangat berpengaruh bagi kehidupan mereka. Dalam cerita Murwakala tersebut, diceritakan dari awal mula terciptanya sosok Bathara Kala hingga penyucian segala sukerta (kekotoran) di tempat pertunjukan wayang tersebut. Hal yang menarik adalah sosok Bathara Kala dalam cerita Murwakala tersebut sebagai sosok raksasa yang bersifat arogan (berangasan), serakah, dan susah diatur, akan tetapi bisa menunjukkan kesucian yang dimilikinya dengan mematuhi peraturan yang ada dan menghormati dhalang Kandha Buwana sebagai orang yang lebih tua darinya. Rupanya dari hal ini, muncul ide yang diolah menjadi gagasan, yaitu sosok Bathara Kala yang dilihat dari sifat/karakter dan kisahnya dalam cerita Murwakala dengan wujud empat nafsu yang ada dalam diri manusia. Dengan 
demikian, rangsang yang digunakan adalah rangsang gagasan.

\section{Tema Tari}

Sosok Bathara Kala yang dilihat dari sifat/karakter dan kisahnya dalam cerita Murwakala menjadi gagasan untuk menciptakan karya koreografi. Tentu setiap orang memiliki sudut pandang masing-masing terhadap sosok Bathara Kala dalam cerita Murwakala. Dalam karya ini sosok Bathara Kala dalam cerita pewayangan Jawa dikenal sebagai sosok yang arogan (berangasan), serakah, dan susah diatur, namun dapat menunjukkan kesuciannya dengan sifat tenang dan patuh terhadap aturan yang ada dalam suatu situasi. Hal ini relevan dengan empat nafsu manusia, yaitu amarah, aluwamah, supiah, dan mutmainah. Konsep "kiblat papat lima pancer" yang berarti "empat arah yang ke lima pancer" di Jawa dapat dipinjam untuk mengungkapkan permasalahan dan sekaligus menjadi tema karya Pat Pinurba.

\section{Judul Tari}

Berdasarkan rangsang dan tema tari di atas terdapat sebuah fenomena menarik, yaitu pengendalian Kala dalam diri manusia yang berwujud empat nafsu manusia. Metode meditasi atau dalam bahasa Jawa Kuno dipadankan dengan kata manekung digunakan sebagai upaya untuk mengendalikan empat nafsu yang ada dalam diri koreografer maupun pendukung karya Pat Pinurba. Hal ini menjadi ide garap untuk menciptakan karya koreografi dengan judul Pat Pinurba. Judul ini diambil dari bahasa Sanskerta, Pat berasal dari kata papat yang berarti empat, sedangkan Pinurba berasal dari kata purba yang berarti kekuasaan. Pinurba sendiri memiliki arti dikuasai. Jadi, Pat Pinurba dapat dimaknai sebagai empat yang dikuasai/dikendalikan. Dengan demikian, secara tidak langsung judul ini diharapkan dapat menginformasikan kepada penonton bahwa sejatinya empat nafsu (Kala) dapat dikendalikan oleh diri manusia itu sendiri.

\section{Bentuk Tari}

Bentuk karya tari Pat Pinurba yaitu bentuk dramatik. Sesuai dengan tema yang diusung dalam karya ini, dramatik di setiap bagian diolah dalam koreografi kelompok dengan berganti-ganti karakter sebagai visualisasi dari empat nafsu manusia dan pengendaliannya. Selain itu, pengendalian empat nafsu tersebut juga akan diungkapkan secara simbolis dengan menggunakan properti.

\section{Cara Ungkap}

$$
\text { Cara ungkap simbolis yang }
$$
digunakan yaitu mengungkapkan ide/gagasan dan tema dengan menampilkan simbol-simbol yang membuat penonton tidak secara langsung 
dapat memahami isi karya Pat Pinurba. Bahkan, bisa saja penonton memiliki interpretasi yang berbeda ketika melihat karya tari ini. Kata simbol berasal dari kata Yunani, symbolos yang berarti tanda atau ciri yang memberitahukan sesuatu hal kepada orang lain. Cara ungkap simbolis yang digunakan bukan untuk menerangkan ataupun menguraikan karena semakin diberi keterangan dan penjelasan-penjelasan, semakin berkurang juga daya simbolisnya. Karya tari Pat Pinurba merupakan hasil karya yang terdiri dari gagasan-gagasan, simbolsimbol, dan nilai-nilai yang terkandung di dalamnya. Oleh sebab itu, konsep cara ungkap simbolis dipinjam untuk mengungkapkan karya tari Pat Pinurba karena pada dasarnya menurut Budiono Herusatoto, manusia merupakan makhluk yang bersimbol.

\section{Gerak}

Esensi kualitas gerak lembut dan keras (kendho dan kenceng) serta kualitas gerak dengan tempo lambat/pelan dalam teknik tari alusan Jawa yang tenang, mengalir, lambat, dan detail menjadi inspirasi dasar untuk mengekspresikan empat nafsu manusia. Bambang Suryono mengatakan bahwa "hanya dengan pelan kita bisa melihat yang detaildetail. Indra kita semakin tajam". Menurut S.Ngaliman bergerak dengan kualitas lambat, terkendali, tenang, dan detail, dapat dianalogikan dalam tari Jawa karakter alusan yang ditarikan dengan konsep mbanyu mili dan ganggeng kanyut. Semua gerakan terkontrol atas semua pergerakan persendian dan kendho kenceng otot, disertai pernafasan yang terkoordinasi dengan gerak tangan, kaki, kepala, dan tubuh. Tidak ketinggalan menahan emosi atau menetralkan pikiran memusatkan pada konsistensi gerak yang mengalir secara terus menerus dari awal hingga akhir tarian. Kualitas gerak alusan tersebut digunakan pada karya Pat Pinurba sebagai metode untuk mengenali gerak diri sendiri secara detail dan fokus. Selain itu, proses olah rasa dengan metode yang digunakan menjadi peran penting untuk mengembangkan gerak-gerak yang sesuai dengan konsep yang dibutuhkan.

\section{Penari}

Karya Pat Pinurba diekspresikan melalui delapan penari dengan rincian empat penari putri dan empat penari putra. Pemilihan para penari didasarkan pada pencarian dengan cara bermeditasi olah rasa. Pemilihan penari putri yang berjumlah empat sebagai interpretasi dari Kala yang berwujud empat nafsu dalam tubuh manusia. Satu penari putra sebagai simbol diri manusia yang berusaha untuk mengendalikan diri untuk mencapai keseimbangan, keselarasan, dan ketentraman dalam kehidupan. Sedangkan tiga penari putra merupakan refleksi suasana batin oleh diri 
manusia. Sebagaimana manusia membutuhkan perjuangan untuk mengendalikan nafsunya. Selain itu, tiga penari tersebut dibutuhkan untuk memainkan properti yang digunakan pada saat pertunjukan berlangsung.

\section{Musik Tari}

Berdasarkan pengamatan terhadap cerita Murwakala, bahwa ketika Dhalang Kandha Buwana membaca rajah-rajah yang ada di tubuh Bathara Kala menggunakan kidung (mantera-mantera). Hal tersebut menjadi inspirasi untuk mengolah seni vokal dalam karya Pat Pinurba. Karya Pat Pinurba menggunakan musik live (langsung). Untuk mendukung suasana yang sesuai dengan konsep, karya Pat Pinurba menggunakan instrumen kemanak, rebab, suling, gong cina, jemblung, lonceng, genta dan kuntulan. Rebab dan suling digunakan untuk membangun suasana lembut, mengalun, dan sakral. Sedangkan bedug dan gong cina merupakan instrumen perkusi yang digunakan untuk suasana keras dan tegang. Namun, tidak menutup kemungkinan bahwa semua instrumen tersebut dapat membangun semua suasana yang dibutuhkan. Begitu juga instrumen-instrumen lainnya tentu digunakan untuk membangun suasana karya tari.

\section{Rias dan Busana}

Rias yang digunakan dalam karya Pat Pinurba terinspirasi dari tata rias pada tari Bedhaya gaya Yogyakarta dengan konsep meditatif. Hal ini diamati bahwa pada tari Bedhaya tidak berekspresi layaknya tari Golek yang berekspresi kemayu, melainkan berekspresi dari dalam hati dan fokus untuk mencapai kekhusukan menjadi satu tubuh. Dasar tata rias yang berwarna kuning digunakan untuk memperdalam makna meditatif.

Busana yang dikenakan pada karya Pat Pinurba terinspirasi dari tradisi Yogyakarta, yaitu metode pewarnaan kain dengan teknik celup ikat yang dikembangkan sesuai dengan kebutuhan konsep karya. Warna yang dipilih untuk mengekspresikan karya Pat Pinurba didominasi oleh warna putih, merah, kuning, dan hitam. Pemilihan warna tersebut merupakan anasir empat nafsu manusia. Putih sebagai anasir nafsu mutmainah, merah sebagai anasir nafsu amarah, kuning sebagai anasir nafsu supiah, dan nafsu aluwamah memiliki anasir warna hitam. Busana yang dikenakan terinspirasi dari celana tradisional Thailand yang dirasa sesuai dengan konsep yang dibutuhkan dan nyaman saat digunakan menari. Busana yang dikenakan penari putri yaitu selembar kain berukuran $75 \mathrm{~cm}$ X $300 \mathrm{~cm}$ dibentuk menjadi celana dengan panjang di atas lutut dan selembar kain berukuran $15 \mathrm{~cm}$ 
X $250 \mathrm{~cm}$ dikenakan untuk menutupi bagian dada. Sedangkan busana penari putra menggunakan celana dengan model yang sama. Hanya saja tidak menggunakan penutup dada.

\section{Pemanggungan}

Karya Pat Pinurba diciptakan dengan orientasi garap koreografi ruang proscenium stage. Ruang proscenium stage mempunyai kekuatan yang luar biasa untuk menciptakan aspek proyeksi yang bisa ditangkap oleh penonton, baik yang bersfat fisikal maupun bersifat imajiner. Penggunaan proscenium stage sebagai ruang pertunjukan merupakan salah satu upaya untuk memperkuat konsep karya Pat Pinurba dengan mengolah komposisi sesuai dengan hasil mengolah rasa agar menjadi karya yang sesuai dengan pesan yang ingin disampaikan.

Set dan properti yang digunakan berupa wajan (penggorengan) dengan ukuran besar. Properti ini digunakan berdasarkan pencarian dengan cara olah rasa (meditasi). Wajan digunakan untuk mengekspresikan ke empat nafsu manusia (Mutmainah, Amarah, Supiah, dan Aluwamah). Wajan sebagaimana mestinya berfungsi untuk menyatukan semua bahanbahan makanan hingga menjadi masakan yang matang. Begitu juga pada properti wajan dimaknai sebagai alat untuk menyatukan empat nafsu dan mengolahnya untuk diseimbangkan hingga menjadi manusia yang matang (dapat mengendalikan nafsunya).

Karya Pat Pinurba menggunakan video mapping sebagai pendukung karya. Video mapping merupakan teknik pencahayaan dan proyeksi yang menciptakan ilusi optis pada suatu objek, benda, atau bidang. Hal ini dibutuhkan untuk mengungkapkan beberapa bagian yang kurang bisa diekspresikan melalui gerak. Sehingga menggunakan media video mapping untuk mendukung karya Pat Pinurba.

Pencahayaan yang digunakan pada karya Pat Pinurba bersifat special bersuasana. Penataan cahaya disadari sebagai efek penunjang yang diharapkan memberi kesan kepada penonton tanpa harus menarik perhatian yang berlebihan terhadap efek cahayanya. Pencahayaan yang bersuasana dibutuhkan untuk mendukung suasana-suasana tiap adegan dalam karya Pat Pinurba di antaranya; suasana tenang, suasana mistis/sakral, suasana tegang dan suasana romantis. Karena karya Pat Pinurba menggunakan video mapping, maka membuat pencahayaan yang digunakan membutuhkan banyak special light. Hal ini disebabkan bias cahaya lampu harus diminimalisir agar tidak mengganggu kejelasan video mapping . 


\section{B. Realisasi Karya}

Proses penciptaan karya tari Pat Pinurba tentu melalui berbagai proses kreatif dari pembentukan konsep hingga perwujudan konsep tersebut. Perwujudan konsep ini kemudian membuahkan hasil, yaitu keutuhan karya secara menyeluruh dalam bentuk ikatan rasa yang harmonis antar pendukung maupun bentuk fisik karya tari ini. Pada sub bab ini, akan dipaparkan bentuk fisik yang telah dicapai selama berproses.

Hasil karya tari Pat Pinurba tentu diperoleh tak lepas dari kontribusi seluruh pendukung baik penari, pemusik, tim kesejahteraan, tim instrumen, tim busana, operator cahaya, tim pelaksana teknis produksi, dan seluruh pendukung yang terlibat dalam karya tari ini. Para pendukung dan orang-orang terdekat selalu memberi semangat dan masukan agar terus melangkah menuju akhir dari proses ini sehingga mencapai hasil yang diharapkan. Hasil dari proses penciptaan yang meminjam metode ritus bima suci, pendekatan sensasi ketubuhan, sensasi emosi, sensasi imaji, dan ritus ekspresi, terbentuklah sebuah karya Pat Pinurba dengan durasi kurang lebih 21 menit. Dinamika yang dibangun oleh kedekatan seluruh pendukung menjadikan satu kesatuan rasa dalam karya tari ini. Berikut uraian hasil yang telah dicapai dalam karya Pat Pinurba:

\section{Segmen Satu}

Segmen ini merupakan segmen pertama yang mengomunikasikan tentang konsep Jawa "sedulur papat lima pancer" (saudara empat lima pancer). Setelah Islam masuk ke Nusantara, ajaran Kejawen mendapat pengaruh dari Arab. Sedulur papat lima pancer kemudian diartikan pula sebagai empat macam nafsu manusia yakni nafsu Aluwamah (kenikmatan biologis/kepuasan ragawi), nafsu Amarah (emosional), nafsu Sufiyah (kenikmatan psikologis/kepuasan batin), dan nafsu Mutmainah (kemurnian dan kejujuran). Sedangkan yang ke lima yakni pancer (pusat), diwujudkan sebagai pengendali utama atas keempat nafsu tersebut yaitu hati nurani manusia.

Pada segmen ini, ditampilkan video tugu Pal Putih Yogyakarta, bentuk segi empat pada tugu memiliki makna sebagai lambang empat kiblat. Selain itu, segi empat juga membentuk ornamen, yaitu wajikan. Pemahaman tersebut dipahami sebagai konsep "kiblat papat lima pancer'. Kemudian muncul simbol kawung berwarna coklat yang kemudian masingmasing bentuk berubah warna menjadi empat warna yakni merah, kuning, putih, dan hitam sebagai simbol anasir empat nafsu manusia yang telah dipaparkan di atas. Kawung berputar-putar layaknya mengikuti waktu yang terus berjalan diikuti oleh nafsu-nafsu manusia tersebut. Kawung terbelah, masing-masing 
bentuk dan warnanya muncul satu per satu mulai dari putih, merah, kuning, kemudian hitam. Setelah itu, muncul partikel-partikel cahaya empat warna yang berputar-putar kemudian ke atas dan akhirnya masuk pada tubuh penari laki-laki yang sudah siap di depan layar.

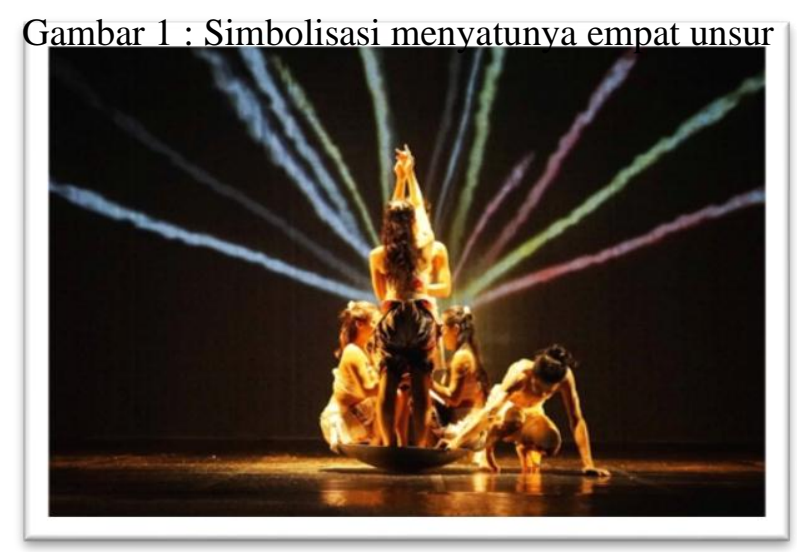

(anasir nafsu, anasir alam, anasir warna, anasir arah mata angin)

Foto: Romeo, 2018

\section{Segmen Dua}

Segmen dua diawali dengan empat penari perempuan dan satu penari laki-laki yang berada di panggung. Segmen ini mengekspresikan empat hawa nafsu manusia yang diungkapkan melalui empat anasir alam, yakni air, api, tanah, dan udara. Air merupakan anasir dari nafsu Mutmainah, api adalah anasir dari nafsu Amarah, tanah adalah anasir Aluwamah, dan udara merupakan anasir Sufiyah.

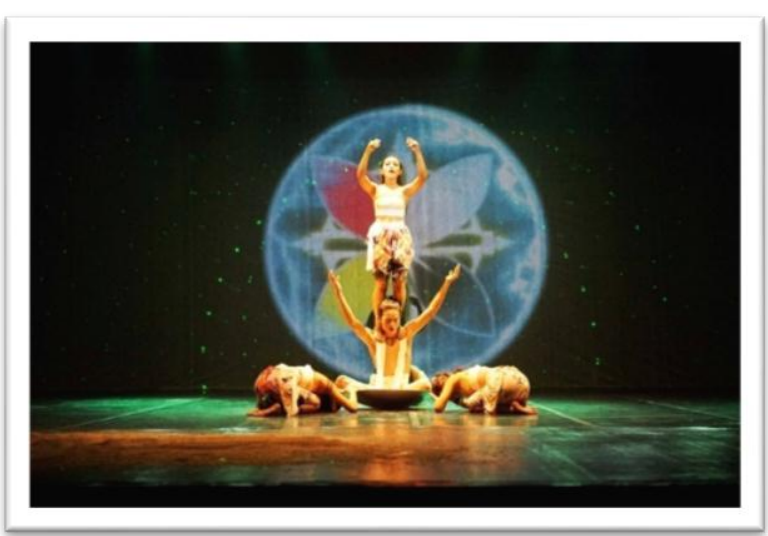

Gambar 2 : Sikap gerak penari mengekspresikan berserah diri kepana Tuhan YME.

(Foto: Romeo, 2018)

\section{Segmen Tiga}

Segmen tiga merupakan segmen yang mengekspresikan menyatunya empat anasir alam pada tubuh manusia. Empat anasir alam tersebut kemudian menjadi empat nafsu yang bernaung pada diri manusia. Selain itu, dipaparkan juga perjuangan manusia dalam upaya mengendalikan diri dari empat nafsu tersebut. Hal ini menjadi poin penting dalam mengendalikan diri. Unsur-unsur keseimbangan juga ditampilkan pada segmen ini. Misalnya, empat penari putri yang masuk pada properti wajan berdiameter $80 \mathrm{~cm}$ kemudian berdiri dan bergerak. Sembari empat penari perempuan bergerak di atas wajan, penari laki memutarkan wajan tersebut searah jarum jam. Tentu hal ini sangat membutuhkan keseimbangan. Selain itu, semua penari juga 
dituntut untuk saling percaya satu sama lain. Contoh kedua, ketika tiga penari laki-laki menari membawa wajan di atas punggung tanpa dipegang. Hal ini tentu juga membutuhkan kesimbangan yang tinggi.

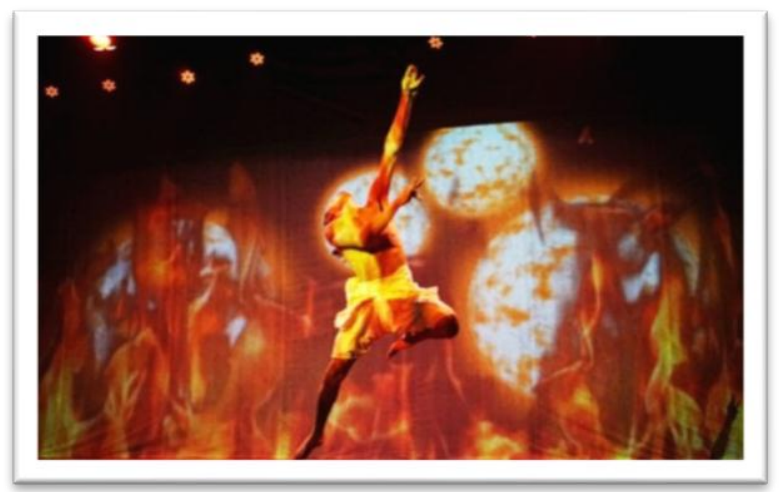

Gambar 3 : Sikap gerak penari pada motif handahana.

(Foto: Romeo, 2018)

\section{Segmen Empat}

Segmen empat merupakan segmen terakhir. Pada segmen ini diekspresikan perjuangan manusia untuk menuju pada satu tujuan, yaitu kemurnian jiwa. Perjuangan manusia yang ditampilkan berupa wajan yang dipegang oleh empat penari perempuan dan penari laki-laki berada di bawah wajan. Semua penari dituntut untuk merasakan dan mengikuti kemana arah wajan tersebut ingin bergerak. Hal ini sebagai simbol bahwa manusia pasti mengikuti arus kehidupan yang sudah digariskan oleh Tuhan Yang Maha Esa. Hanya saja manusia perlu berusaha untuk bisa mengerti, memecahkan masalah, dan mencari solusi dari semua permasalahan yang dihadapinya. Selain itu, ditampilkan pula perjalanan manusia untuk menuju kemurnian jiwanya. Empat penari perempuan dan satu penari laki-laki bergerak menuju satu tujuan yang sama, satu rasa, dan satu titik fokus hingga sampai pada tempat yang dituju. Setelah berusaha untuk mencapai tujuan yang diinginkan, kemudian berserah diri kepada Tuhan Yang Maha Esa.

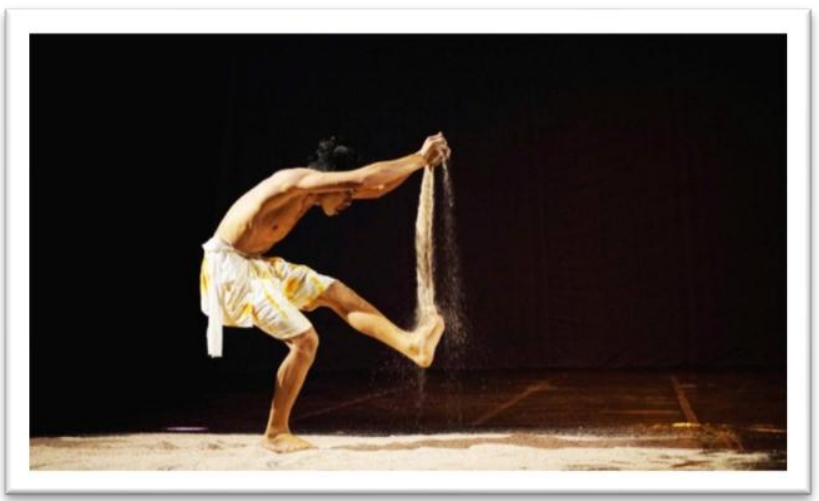

Gambar 4 : Sikap gerak penari pada motif nglemah.

(Foto: Romeo, 2018)

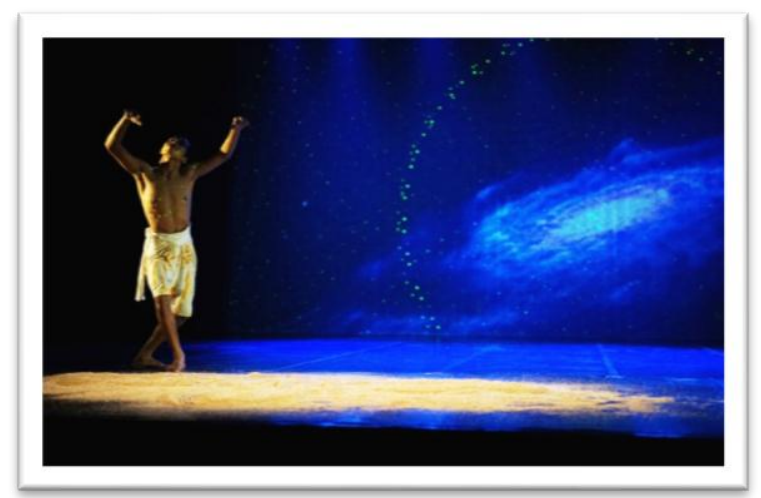

Gambar 5 : Sikap gerak penari pada motif mbayu. (Foto: Romeo, 2018) 
Keseimbangan dan rasa saling percaya antar

\section{PENUTUP}

Proses kreatif selama kurang lebih 3 bulan menghasilkan sebuah karya tari yang berdurasi kurang lebih 21 menit. Karya tari yang berlatar belakang cerita murwakala dalam pewayangan masyarakat Jawa menghasilkan karya tari yang berbasis tradisi pula. Penciptaan karya tari berjudul Pat Pinurba merupakan wujud penuangan ide kreatif yang dilatarbelakangi oleh ketertarikan terhadap karakter Bathara Kala pada cerita murwakala. Dapat diinterpretasikan bahwa sesungguhnya karakter Bathara Kala ada dalam diri manusia dalam wujud empat nafsu. Empat nafsu tersebut meliputi nafsu Mutmainah, Amarah, Supiah, dan Lauamah. Empat nafsu inilah yang kemudian menjadi kegelisahan tersendiri untuk dikendalikan dan diseimbangkan, layaknya Bathara Kala yang ditaklukkan oleh Dhalang Kandha Buwana.

Karya tari ini mengungkapkan pengendalian diri manusia terhadap empat nafsu yang ada pada dirinya. Empat nafsu manusia tersebut diekspresikan melalui empat anasir alam, yaitu air, api, tanah, dan udara. Masing-masing anasir alam memiliki sifat dan karakternya yang dapat mengekspresikan empat nafsu manusia. Menyatunya empat anasir alam pada tubuh manusia juga diungkapkan di karya Pat Pinurba. penari menjadi poin penting untuk mewujudkan karya tari ini. Selain itu, disuguhkan pula perjuangan manusia untuk menuju pada satu tujuan, yaitu kemurnian jiwa. Empat penari perempuan dan satu penari laki-laki bergerak menuju satu tujuan yang sama, satu rasa, dan satu titik fokus hingga sampai pada tempat yang dituju. Setelah berusaha untuk mencapai tujuan yang diinginkan, kemudian berserah diri kepada Tuhan Yang Maha Esa.

Konsep kehidupan masyarakat Jawa "kiblat papat lima pancer" yang memiliki makna empat arah (unsur) yang kelima adalah pusatnya memiliki kontribusi yang sangat besar terhadap proses penggarapan karya tari Pat Pinurba. Konsep tersebut bukan hanya menjadi inspirasi dasar yang kemudian menjadi ide gagasan karya ini, akan tetapi konsep tersebut juga disuguhkan melalui anasir-anasir alam yang dikemas menggunakan gerak tari maupun video mapping.

Karya tari Pat Pinurba disuguhkan sebagai sebuah bentuk ekspresi untuk mengupas pengendalian diri manusia terkait dengan empat nafsu yang dimiliki. Adapun kesan-kesan koreografer selama berproses adalah pada awalnya kurang bisa mengendalikan diri terhadap empat nafsunya sendiri, kini mulai bisa mengendalikan diri 
sedikit demi sedikit. Tentunya mendapatkan pengalaman berkarya yang berguna untuk berproses kreatif selanjutnya maupun di kehidupan sehari-hari. Pada saat proses penciptaan karya tari ini, ditemukan kendalakendala yang pada akhirnya dapat terselesaikan dengan menanamkan sikap tenang, sabar, berserah diri dan semeleh. Menanamkan sikap-sikap tersebut, proses kreatif karya tari Pat Pinurba menjadi lebih lancar dan sesuai dengan harapan. Selain itu, selama dan setelah proses penciptaan, koreogafer beserta beberapa pendukung karya menjadi lebih peka terhadap diri sendiri dan energi lingkungan sekitar.

\section{DAFTAR SUMBER ACUAN}

\section{A. Daftar Pustaka}

Chodjim, Achmad. Sunan Kalijaga: Mistik dan Makrifat. Jakarta: Serambi Ilmu Semesta. 2003.

. Sunan Kalijaga: Mistik dan Makrifat, edisi revisi. Jakarta: Serambi Ilmu Semesta. 2013.

Endraswara, Suwardi. Mistik Kejawen: Sinkretisme, Simbolisme, dan Sufisme dalam Budaya Spiritual Jawa. Yogyakarta: Narasi. 2006.

Giri MC, Wahyana. Sajen dan Ritual Orang Jawa. Yogyakarta: Narasi. 2010.
Hadi, Y. Sumandiyo. Aspek-Aspek Dasar Koreografi Kelompok. Yogyakarta: Manthili. 1996.

Koreografi: Bentuk-

Teknik-Isi. Yogyakarta: Cipta Media. Cetakan kelima, 2017.

Koreografi: Ruang

Prosenium. Yogyakarta: Cipta Media. Cetakan pertama, 2017.

Hawkins, Alma M. Creating Trough Dance. Los Angeles. dialihbahasakan oleh Y. Sumandiyo Hadi. Mencipta Lewat Tari. Yogyakarta. 1990.

Herusatoto, Budiono. Simbolisme Dalam Budaya Jawa. Yogyakarta:

PT.Hanindita Graha Widya. 1991.

Kamajaya, H. Karkono, dkk. Ruwatan Murwakala: Suatu Pedoman. Yogyakarta: Duta Wacana University Press. 1996.

Kusrianto, Adi. Batik: Filosofi, Motif \& Kegunaan. Yogyakarta: Andi Offset. 2013.

Martono, Hendro. Mengenal Tata Cahaya Seni Pertunjukan. Yogyakarta: Cipta Media. 2010.

Koreografi Lingkungan, Revitalisasi Gaya Pemanggungan dan Gaya Penciptaan Seniman Nusantara. Yogyakarta: Cipta Media. 2012.

Ruang Pertunjukan dan Berkesenian. Yogyakarta: Multi Grafindo. 2012.

. Buku Ajar Ziarah Ragawi: Meningkatkan Kualitas Ketubuhan. Yogyakarta: Cipta Media. 2016.

Morin, Lutse Lambert Daniel. "Problematika Tugu Yogyakarta dari Aspek Fungsi dan Makna", dalam Journal of Urban: 
Society's Arts Vol. 1 No. 2,

Yogyakarta: Fakultas Seni Rupa ISI Yogyakarta. 2014.

Rusdy, Sri Teddy. Ruwatan Sukerta dan Ki

Timbul Hadiprayitno. Jakarta: Yayasan Kertagama. 2012.

Subalidinata, R.S., dkk. Sejarah dan Perkembangan Cerita Murwakala dan Ruwatan dari Sumber-sumber Sastra Jawa. Departemen Pendidikan dan Kebudayaan Direktorat Jendral Kebudayaan Proyek Penelitian dan Pengkajian Kebudayaan Nusantara (Javanologi). 1985.

Sumardjo, Jakob. Estetika Paradoks, edisi revisi. Jawa Barat: Sunan Ambu Press. 2010.

Susetya, Wawan. Empat Hawa Nafsu Orang Jawa. Yogyakarta: Narasi. 2016.

Trisusilowati, Trisno. "Murwakala Dalam Ruwatan Sukerta: Sebuah Kajian Sosiologi Teater", dalam Jurnal Surya Seni: Jurnal Penciptaan dan Pengkajian Vol. 5 No. 1. Yogyakarta: Program Pascasarjana ISI Yogyakarta. 2009.

Wijayanti, Jiyu. "Nrtta Nirbhaya", dalam Jurnal Surya Seni: Jurnal Penciptaan dan Pengkajian Vol. 2 No. 1.

Yogyakarta: Program Pascasarjana ISI Yogyakarta. 2006.

\section{B. Discografi}

Karya tari Kala Takluk oleh Oky Bima Reza Afrita. Dipentaskan pada tanggal 19 Desember 2017 di Proscenium Stage Jurusan Tari, Fakultas Seni Pertunjukan, Institut Seni Indonesia Yogyakarta.

Karya tari Seser oleh Galih Puspita Karti. Dipentaskan pada tahun 2014 di
Proscenium Stage Jurusan Tari,

Fakultas Seni Pertunjukan, Institut Seni Indonesia Yogyakarta.

Karya tari Be Your Self oleh Australian Dance Theatre. Dipentaskan pada Juni 2012 di Sidney Theatre. 